\section{Reduced Tillage Alternatives for Machine-harvested Cucumbers}

\author{
Sheryl K. Lonsbary and John O'Sullivan \\ Department of Plant Agriculture, University of Guelph, Simcoe, ON N3Y 4N5, \\ Canada
}

\section{Clarence J. Swanton \\ Department of Plant Agriculture, University of Guelph, Guelph, ONN1G 2W1, Canada}

Additional index words. Cucumis sativus, zone tillage, no tillage, conventional tillage, reduced tillage

\begin{abstract}
Cucumber (Cucumis sativus $\mathbf{L}$.) is grown using intensive tillage practices, which increase the cost of production and may lead to an increase in soil and water erosion. Research on alternative tillage practices for cucumber production has been limited primarily to exploring the benefits of no tillage. Alternative tillage practices, such as disking (one pass with a tandem disk) and zone tillage (one pass with a Trans-till) have not been investigated. Thus, the objective of this study was to compare the influence of reduced tillage practices on the growth, development, and yield of cucumbers. Seedling emergence varied between years, but was unaffected by a reduction in tillage, while cucumber leaf number, leaf area index, and vine growth were reduced by no tillage $(P \leq 0.05)$. Total dry matter accumulation and days to $50 \%$ open flower varied with tillage. No-tillage plots produced an average of $34 \mathrm{~g} \cdot \mathrm{m}^{-2}$ of dry matter compared to $47 \mathrm{~g} \cdot \mathrm{m}^{-2}$ for conventional tillage plots and took 1 day longer to reach $50 \%$ flower. Although growth differences were observed under all reduced tillage treatments, no reduction in total yield was observed when compared with conventional tillage yields. Alternative reduced tillage practices, such as disking or zone tillage, were found to be viable options for successful cucumber production. These alternative practices will reduce the cost of production, provide growers with greater time flexibility and ease of land preparation, and reduce the potential for water and wind erosion.
\end{abstract}

Processing cucumbers are a high value crop in North America and the industry continues to grow. In the United States, 42,400 ha of processing cucumbers were harvested in 2000 , producing a gross farm gate value of $\$ 165$ million [U.S. Dept. of Agriculture (USDA), 2001a] while in Ontario, 2680 ha of cucumbers with a farm gate value of $\$ 11.3$ million were harvested that same year [Ontario Processing Vegetable Industry (OPVG), 2001a; Ontario Ministry of Agriculture, Food, and Rural Affairs (OMAFRA), 2001. From 1996 to 2000, farm gate value for cucumber production increased by $15 \%$ in the United States and $59 \%$ in Ontario (OPVG, 2001a; OMAFRA, 2001; USDA, 2001b). In Ontario alone, the number of hectares devoted to cucumber production has doubled within the last 5 years (OMAFRA, 2001).

With this rapid expansion, questions have been raised as to whether the current tillage practices used for cucumber production can be sustained (NeSmith et al., 1994). As with many other vegetable crops, cucumbers are generally managed with tillage-intensive production practices, such as plowing and repeated cultivations. Intensive-tillage leads to soil degradation, erosion, and compaction, and water loss through evaporation and surface runoff (Griffith et al., 1986; Singh and Sainju, 1998). As an alternative to current tillage

Received for publication 29 July 2002. Accepted for publication 23 Apr. 2003. practices, opportunities may exist to utilize tillage practices that reduce production costs, conserve soil moisture, and reduce soil and water erosion.

Reduced tillage is more widely accepted for use in field crops than in vegetable crop production. Previous field crop studies have shown that reduced tillage can contribute to a reduction in soil degradation, erosion and compaction, and an increase in available soil moisture (Gallaher, 1977; Janovicek and Vyn, 1992; Jones et al., 1969; Raghavan et al., 1979). Yield results on the potential role for reduced tillage in vegetable crops have been variable. No tillage was found to maintain or improve yields, compared to conventional tillage, for cabbage, cucumber, pumpkin, squash, and sweet corn (Galloway and Weston, 1996; Knavel and Morrison, 1977; Morse, 1993; Morse et al., 1982; NeSmith et al., 1994). Bottenberg et al. (1999) and Knavel and Morrison (1977), however, reported better yields of pepper, snapbean, and tomato grown under conventional tillage practices compared to no tillage. To date, research on cucumber production has compared no tillage to conventional tillage (Knavel and Morrison, 1977; Morse et al., 1982); however, there is no information on the potential for reduced tillage, such as disked tillage or zone tillage, as alternative tillage practices for cucumber production.

The implementation of reduced tillage alternatives for cucumber production may result in economic and environmental benefits. The hypothesis for this study was that cucumbers grown under reduced tillage would not differ in growth, development, and yield compared to those grown using conventional tillage.

\section{Materials and Methods}

Experiments were conducted in 2000 and 2001 at the Horticultural Research Station, Simcoe, Ont., Canada. The soil in 2000 was a Scotland, fine sandy loam soil (gray brown Brunisolic Luvisol) with 64\% sand, $31 \%$ silt, $5 \%$ clay, $1.5 \%$ organic matter, and $\mathrm{pH}$ 5.7. In 2001, the soil was a Bookton, very fine sandy loam soil (gray brown Brunisolic Luvisol) with $65 \%$ sand, $29 \%$ silt, $6 \%$ clay, $2.4 \%$ organic matter, and $\mathrm{pH} 6.4$.

The experiment was designed as a randomized complete block, with four replications. Individual plots were $11.3 \mathrm{~m}$ wide $\times 10 \mathrm{~m}$ long with a 10 -m buffer zone between replications, to allow for equipment movement. Soil tests for fertility were performed in Fall 1999 and 2000. At both test sites, the previous crop was rye. An application of lime at $3 \mathrm{t} \cdot \mathrm{ha}^{-1}$ was applied in Fall 1999 at the time of soil preparation, before seeding a rye (Secale cereale L.) cover crop. Rye was solid seeded with a grain drill in $20-\mathrm{cm}$ rows at $180 \mathrm{~kg} \cdot \mathrm{ha}^{-1}$ in Sept. 1999 and 2000. On 19Apr. 2000 and 23 Apr. 2001, when rye was 20 to $25 \mathrm{~cm}$ in height, glyphosate [ $N$ (phosphonomethyl)glycine] at $0.9 \mathrm{~kg} \cdot \mathrm{ha}^{-1}$ a.i. was applied in $300 \mathrm{~L} \cdot \mathrm{ha}^{-1}$ of water at $200 \mathrm{kPa}$ to all plots using a tractor-mounted sprayer.

Reduced tillage treatments consisted of disked tillage, zone tillage, and no tillage. These treatments were compared to conventional tillage with a moldboard plow. The conventional plots were plowed to a depth of $\approx 15$ to $20 \mathrm{~cm}, 6$ to $10 \mathrm{~d}$ following application of glyphosate. The conventional plots were then reworked 10 to $12 \mathrm{~d}$ before cucumber planting with two passes of a tandem disk and cultivated once to level the seedbed. Disked tillage and zone-tillage treatments were performed 6 to $12 \mathrm{~d}$ before planting the cucumber crop. The disked tillage plots were prepared with one pass of a tandem disk to incorporate residue to a depth of $\approx 10$ to $15 \mathrm{~cm}$. The zone-tillage plots were prepared with one pass of a Trans-Till (Rowtech, Stover, Mich.) to create tilled strips, $23 \mathrm{~cm}$ wide and $15 \mathrm{~cm}$ deep, for planting. A Trans-Till consists of an adjustable subsoiling shank, mounted on a toolbar, centered between two fluted coulters followed by two concave coulters. The no-tillage plots consisted of standing rye left undisturbed until planting.

A no-tillage precision seeder (John Deere Max Emerge Plus-VacuMeter; John Deere Co., Moline, Ill.) was used to seed cucumbers ('Vlaspik M') on 5 June 2000 and 4 June 2001. Each plot consisted of 15 rows, $75 \mathrm{~cm}$ apart with an in-row spacing of $7.5 \mathrm{~cm}$, to give a plant population of 178,000 plants/ha. Immediately following planting, an application of $28 \%$ urea ammonium nitrate (UAN) at 75 $\mathrm{kg} \cdot \mathrm{ha}^{-1}$ was injected into the soil to a depth of $10 \mathrm{~cm}$, using a three-shank applicator. The shanks were centered between the cucumber rows at $75 \mathrm{~cm}$ apart. After application of fertilizer, glyphosate plus glufosinate ammonium 
[2-amino-4-(hydroxymethylphosphinyl)] at $1.3 \mathrm{~kg} \cdot \mathrm{ha}^{-1}$ a.i. (1.26 kg.ha- ${ }^{-1}$ a.i. glyphosate plus $0.042 \mathrm{~kg} \cdot \mathrm{ha}^{-1}$ a.i. glufosinate) plus clomazone $\{2-[($ chlorophenyl)methyl]-4,4was applied broadcast for weed control. The combination of glyphosate plus glufosinate was used to obtain a more rapid burn down of weeds than what would be obtained with glyphosate alone (Button, 1999). This helped to reduce competition between the weeds and the emerging crop. All plots were kept weedfree by hand-weeding throughout the growing season. Recommended cultural practices were followed for fungicide and insecticide applications (OMAFRA, 2000).

Three days before cucumber planting, rye residue was collected in two $1-\mathrm{m}^{2}$ areas per plot from the soil surface in all plots, oven dried at $80{ }^{\circ} \mathrm{C}$ to a constant weight and dry weights recorded. Temperature data loggers (HOBO 4-channel External, Hoskins Scientific Ltd., Burlington, Ont.) were placed in all plots of each replication to record soil temperature at a depth of $5 \mathrm{~cm}$ at 1 -hintervals. Soil moisture was measured using a Trase system (model 6050X1, Soilmoisture Equipment Corp., Santa Barbara, Calif.), which uses time domain reflectometry to measure volumetric water content of the soil. Soil moisture was measured to a $10-\mathrm{cm}$ depth, once per week from planting to harvest. Based on previous experience, this frequency of measurement was deemed sufficient to determine variation in soil moisture between treatments over time.

Growth analyses were performed throughout the season. Emergence was determined by a total daily count of plants (green tissue visible above soil surface) that emerged within two permanent $1.5-\mathrm{m}$ row lengths. Time for $50 \%$ of the plants to produce at least one open flower was recorded daily on 20 consecutively tagged plants, starting at flower initiation. To measure leaf number and vine length per plant, 10 consecutive plants were cut off at soil level, starting about at the two-leaf stage of development, leaves counted, and vines measured. Leaves were separated from the vine and leaf area per plant was measured using a LI-COR 3100 area meter (LI-COR, Lincoln, Nebr.). These 10 plants, including developing fruit, were then combined and dried at $80^{\circ} \mathrm{C}$ to a constant weight to obtain estimates of total aboveground dry matter. These destructive measurements were repeated twice per week until 1 week before harvest, when only one measurement was taken.

Cucumbers were harvested by hand on two different harvest dates. In 2000, the crop was dimethyl-3-isoxazolidinone $\}$ at $0.4 \mathrm{~kg} \cdot \mathrm{ha}^{-1}$ a.i.

harvested on 31 July and 2 Aug. and in 2001, on 27 and 30 July. The first sample was harvested when $\approx 10 \%$ of the conventional tillage cucumber plants had fruit greater than $51 \mathrm{~mm}$ in diameter (O'Sullivan and Colwell, 1980). To determine if tillage had any influence on the time of fruit development, the second sample was harvested 2 to $3 \mathrm{~d}$ later from another location within the plot. Yield was taken from one row, $5 \mathrm{~m}$ long, and each sample was graded at each harvest date. Fruit were counted and weighed separately by grade. Total economic yield was determined using the OPVG industry grading and pricing system for processing cucumbers (OPVG, 2001b, 2001c).

All data were subjected to an analysis of variance (ANOVA) using the MIXED and GLM procedures of SAS version 6.12 (SAS Institute, Cary, N.C.) to determine cucumber response to tillage. Data were transformed, where necessary, to normalize and randomly distribute the residuals to satisfy the assumptions of the ANOVA. Studentized residuals were determined for all data and individual measurements were rejected if the critical value was greater than the respective calculated Lund's value (Bowley, 1999). Treatment means were presented as least square means and separated by a pairwise $t$-test, where appropriate. Growth measurements were regressed over time (days after planting) using repeated measures. The Type I error for this experiment was 0.05 .

\section{Results and Discussion}

Soil moisture and temperature. The growing season for 2000 was a much wetter and slightly cooler year than 2001 (Table 1). Soil moisture within all reduced tillage treatments was greater than conventional tillage in 2000 but not in 2001 (Table 2). In 2000, the no-tillage treatment had the highest mean soil moisture content and conventional tillage had the lowest. Greater rye residues present on the soil surface in 2000 may have contributed to the increase in soil moisture retention compared to 2001 (Table 3). A similar response of soil moisture to increasing surface residues has been reported previously. Morse (1993) found fully mulched soil to have more moisture than partially mulched soil. Hooker et al. (1998) found a higher incidence of white bean root rot in no tillage, compared to disked and conventional tillage, which they attributed to prolonged wet conditions observed in the no-tillage plots. In 2001, a combination of higher daily temperatures, lack of rainfall (Table 1), and lower rye residues throughout the growing season may

Table 1. Mean monthly air temperatures and precipitation at Simcoe, Ont., Canada, in 2000 and 2001.

\begin{tabular}{|c|c|c|c|c|c|c|}
\hline \multirow[b]{2}{*}{ Month } & \multicolumn{3}{|c|}{ Temp $\left({ }^{\circ} \mathrm{C}\right)$} & \multicolumn{3}{|c|}{ Precipitation $(\mathrm{mm})$} \\
\hline & 2000 & 2001 & $\begin{array}{c}\text { Normal }^{z} \\
(1962-86)\end{array}$ & 2000 & 2001 & $\begin{array}{c}\text { Normal } \\
(1962-86)\end{array}$ \\
\hline May & 14.4 & 14.7 & 12.6 & 103 & 109 & 74 \\
\hline June & 18.4 & 18.8 & 17.8 & 181 & 63 & 82 \\
\hline July & 19.8 & 20.7 & 20.4 & 146 & 11 & 77 \\
\hline August & 19.7 & 19.5 & 19.5 & 81 & 102 & 80 \\
\hline Mean/total & 18.1 & 18.4 & 17.6 & 128 & 71 & 78 \\
\hline
\end{tabular}

${ }^{2}$ Normal temperature and precipitation values for Simcoe, Ont., for 1962-86. (Source: Canadian Climate Normals, 1961-90. Atmospheric Environment Service, Environment Canada, Ottawa, Canada). have affected the ability of the soil to conserve moisture. Average soil temperatures measured at $5 \mathrm{~cm}$ did not differ with tillage system in either year (data not shown).

Growth and development. Cucumber plant density varied between years but not by tillage treatment. In 2000, it took $14 \mathrm{~d}$ to reach a total plant stand of 120,000 plants/ha, while in 2001 it only took $11 \mathrm{~d}$ to reach the same population (data not shown). The delayed emergence in 2000 may be attributed to the lower soil temperatures, compared to 2001 (Fig. 1), from the time of initial seedling emergence (starting $7 \mathrm{~d}$ after planting) to complete emergence. There was no interaction between tillage and plant population.

The lack of response of cucumber density to tillage was similar to results of Beste (1973), who reported that cucumber plant stands were not reduced when grown under no tillage. Knavel and Morrison (1977), however, found that cucumber density under no tillage was lower than under conventional tillage in the first 2 years of a 3 -year study. In the first 2 years of the study, they used a bluegrass sod for the no-tillage treatments, while in the last year they used a winter wheat cover crop. They attributed the reduction in plant density to inadequate seed furrow closure in the bluegrass sod, compared to the cover crop.

While cucumber density was unaffected by tillage, differences in plant growth were observed. Leaf number, leaf area index, and vine length differed with tillage system and year (Figs. 2, 3, and 4). The final growth

Table 2. Mean soil moisture content at Simcoe, Ont., as influenced by tillage in 2000 and 2001 .

\begin{tabular}{lcc}
\hline & \multicolumn{2}{c}{ Volumetric moisture content $(\%)^{\mathrm{z}}$} \\
\cline { 2 - 3 } Treatment & 2000 & 2001 \\
\hline Conventional & $14.7 \mathrm{~d}^{\mathrm{y}}$ & $13.7 \mathrm{a}$ \\
Disked & $15.5 \mathrm{c}$ & $14.3 \mathrm{a}$ \\
Zone tillage & $16.4 \mathrm{~b}$ & $14.4 \mathrm{a}$ \\
No tillage & $18.1 \mathrm{a}$ & $14.4 \mathrm{a}$ \\
Standard error & 1.05 & 1.06 \\
$P$ value & 0.0001 & 0.0001 \\
\hline
\end{tabular}

${ }^{\mathrm{z}}$ Measured to a depth of $10 \mathrm{~cm}$.

${ }^{y}$ Mean separation within columns, by pairwise $t$ test, $P \leq 0.05$. Values followed by a common letter are not statistically different.

Table 3. Mean dry weight of rye residues present on soil surface at planting, as influenced by tillage at Simcoe, Ont., in 2000 and 2001. Values are back transformed means of sqrt(x) transformed values.

\begin{tabular}{lcc}
\hline & \multicolumn{2}{c}{ Dry wt $\left(\mathrm{g} \cdot \mathrm{m}^{-2}\right)$} \\
\cline { 2 - 3 } Treatment & 2000 & 2001 \\
\hline Conventional & $0 \mathrm{c}^{\mathrm{z}}$ & $0 \mathrm{~d}$ \\
Disked & $79 \mathrm{~b}$ & $46 \mathrm{c}$ \\
Zone tillage & $225 \mathrm{a}$ & $87 \mathrm{~b}$ \\
No tillage & $260 \mathrm{a}$ & $156 \mathrm{a}$ \\
Standard error $^{\mathrm{y}}$ & 0.6 & 0.6 \\
$P$ value $^{\mathrm{x}}$ & 0.0003 & 0.0003 \\
\hline
\end{tabular}

${ }^{2}$ Mean separation within columns, by pairwise $t$ test on transformed means, $P \leq 0.05$. Values followed by a common letter are not statistically different.

${ }^{y}$ Standard error of the mean is for means on the transformed scale.

${ }^{x}$ Probability value based on transformed analysis of variance.

HortScience Vol. 39(5) August 2004 


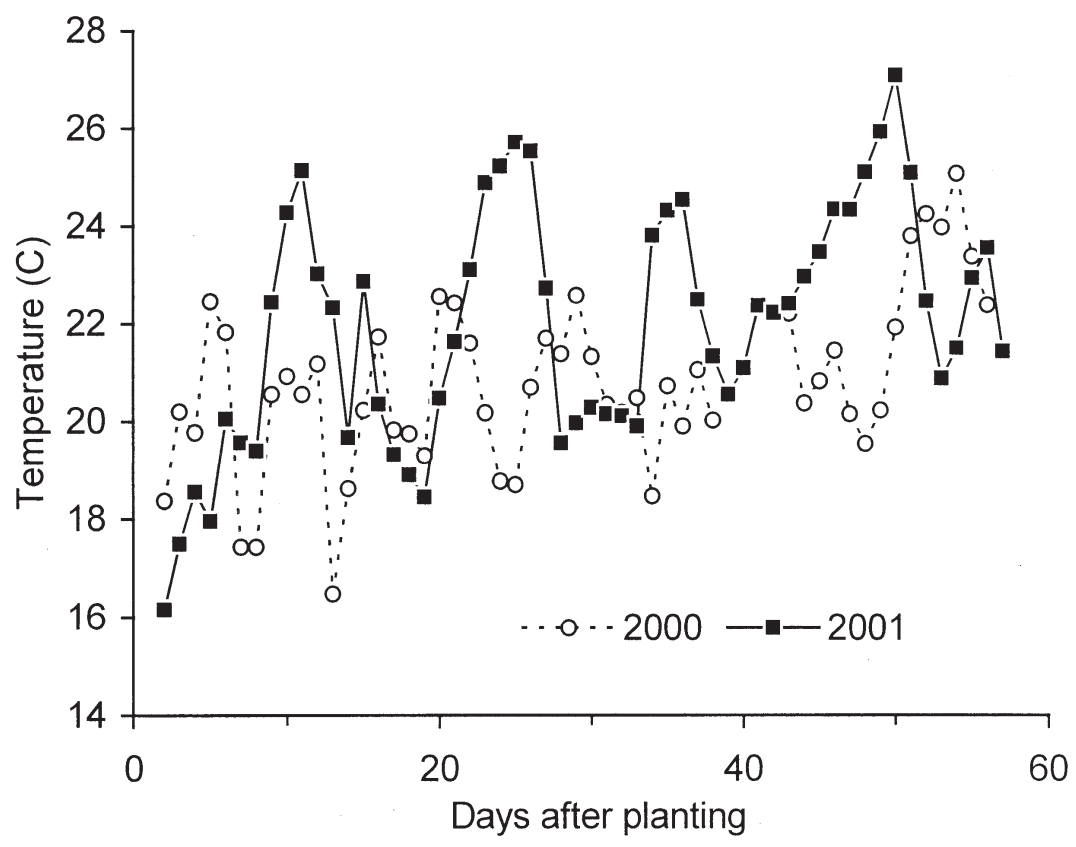

Fig. 1. Daily mean soil temperatures recorded in 2000 and 2001 at a depth of $5 \mathrm{~cm}$. Zero days after planting corresponds to the day of planting, which was 5 June in 2000 and 4 June in 2001.
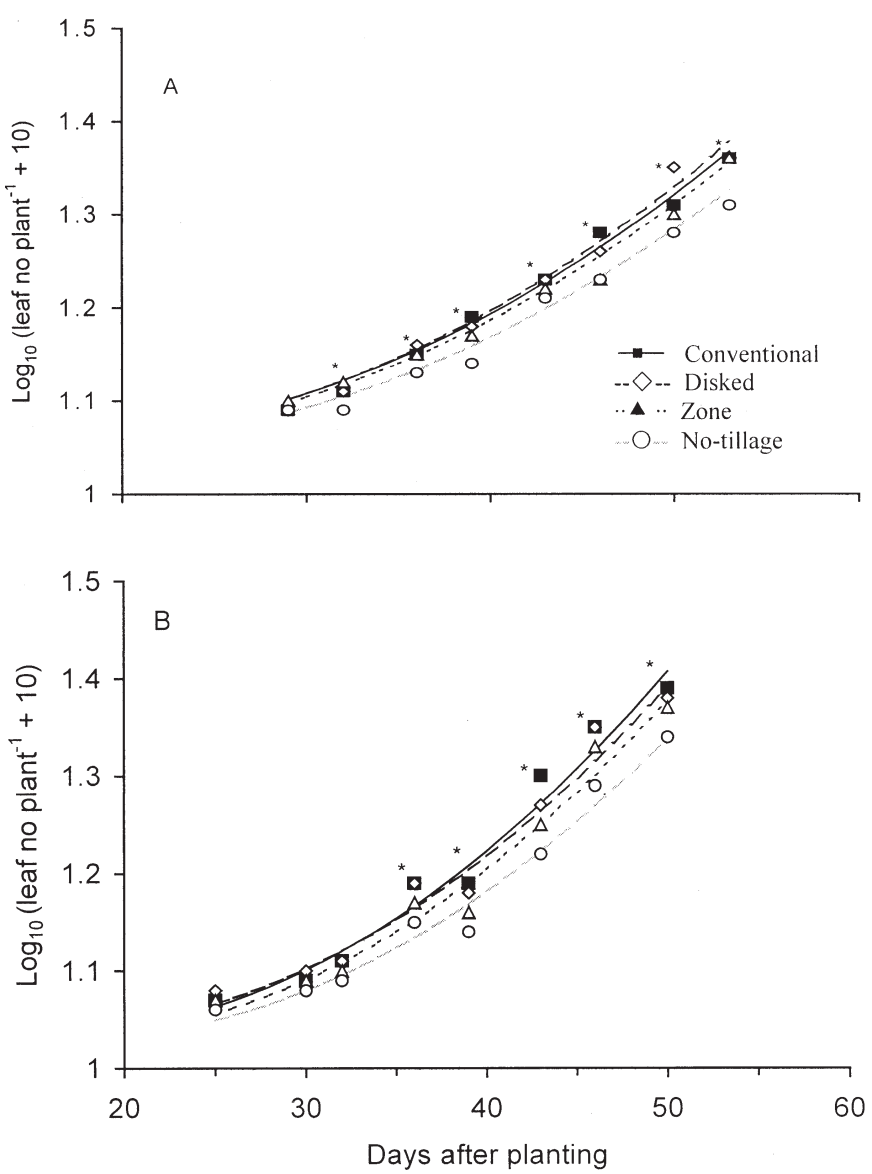

Fig. 2. Leaf number per plant as influenced by tillage [conventional (CT), disked (DT), zone tillage (ZT) and no tillage (NT)] in (A) 2000 and (B) 2001. The asterisks indicate significance differences among treatment means within days, by pairwise $t$ test, $P \leq 0.05$. The regression equations were (A) CT (घ), $\mathrm{y}=1.11-6.34 \times 10^{-3} \mathrm{X}+2.12 \times 10^{-4} \mathrm{X}^{2} ; \mathrm{DT}(\vartheta), \mathrm{y}=1.11-6.61 \times$ $10^{-3} \mathrm{X}+2.21 \times 10^{-4} \mathrm{X}^{2} ; \mathrm{ZT}(\mathbf{\Delta}), \mathrm{y}=1.11-6.33 \times 10^{-3} \mathrm{X}+2.08 \times 10^{-4} \mathrm{X}^{2}$; NT ( $), \mathrm{y}=1.11-6.50 \times 10^{-3} \mathrm{X}+2.00 \times 10^{-4} \mathrm{X}^{2} ;(\mathbf{B}) \mathrm{CT}(\mathbf{\square}), \mathrm{y}=1.11$ $-9.53 \times 10^{-3} \mathrm{X}+3.11 \times 10^{-4} \mathrm{X}^{2} ;$ DT $(\diamond), \mathrm{y}=1.11-8.97 \times 10^{-3} \mathrm{X}+2.93 \times$ $10^{-4} \mathrm{X}^{2} ; \mathrm{ZT}(\mathbf{\Delta}), \mathrm{y}=1.11-9.49 \times 10^{-3} \mathrm{X}+2.98 \times 10^{-4} \mathrm{X}^{2} ; \mathrm{NT}(\mathrm{)}, \mathrm{y}=1.11$ $-9.26 \times 10^{-3} \mathrm{X}+2.78 \times 10^{-4} \mathrm{X}^{2}$. measurements of leaf number and vine length were consistently lower in no-tillage than the other treatments. In 2000, the final number of leaves at $53 \mathrm{~d}$ after planting (DAP) for conventional, disked, and zone till was 13 (back transformed means), while in no tillage there were 11 leaves. In 2001 at 50 DAP, no-tillage cucumbers had 12 leaves, while plants in other plots had 14 or 15 . There were no differences among treatments in leaf area index in 2000 (53 DAP); however, in 2001 (50 DAP) zone tillage was no different from no tillage (Fig. 3). In a similar study, Thomas et al. (2001) observed no differences in leaf number, leaf area index, or plant height, between conventional, disked, zone, and no-tillage treatments for tomato. The general growth patterns observed in this study were in agreement with NeSmith et al. (1994), who found differences between conventional tillage and no-tillage treatments in leaf area for summer squash in the first 3 to 4 weeks of growth.

The reduction in leaf and vine growth between tillage treatments influenced the total aboveground dry matter accumulated over the growing season. Total aboveground dry matter accumulation differed by tillage (Table 4$)$.
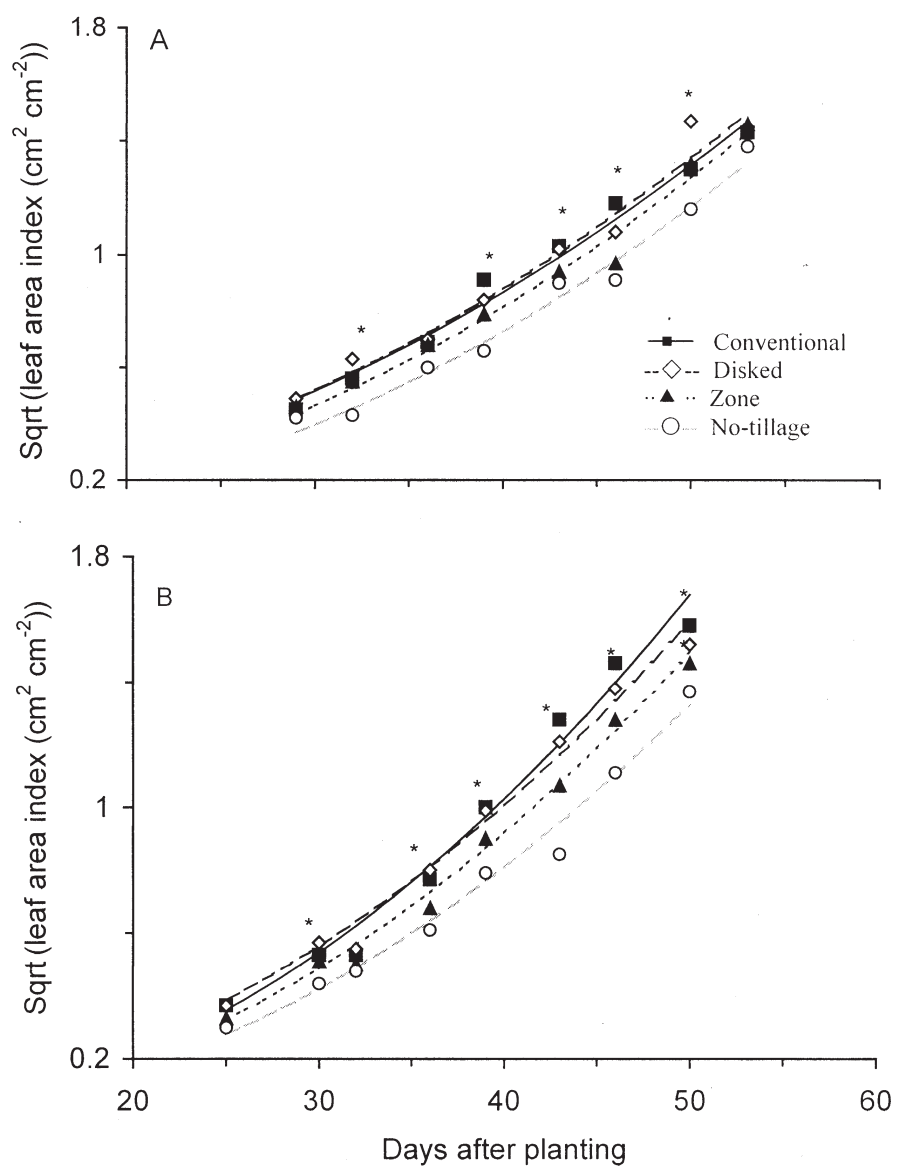

Fig. 3. Leaf area index per plant as influenced by tillage (conventional (CT), disked (DT), zone tillage (ZT) and no tillage (NT)) in (A) 2000 and (B) 2001. The asterisks indicate significance differences among treatment means within days, by pairwise $t$ test, $P \leq 0.05$. The regression equations were (A) CT ( $\mathbf{\square}), \mathrm{y}=$ $\left.5.67 \times 10^{-2}+5.95 \times 10^{-4} \mathrm{X}+4.92 \times 10^{-4} \mathrm{X}^{2} ; \mathrm{DT}(\rangle\right), \mathrm{y}=5.67 \times 10^{-2}+9.99 \times$ $10^{-5} \mathrm{X}+5.11 \times 10^{-4} \mathrm{X}^{2} ; \mathrm{ZT}(\mathbf{\Delta}), 5.67 \times 10^{-2}-2.48 \times 10^{-3} \mathrm{X}+5.35 \times 10^{-4} \mathrm{X}^{2}$; NT ( ), $\mathrm{y}=5.67 \times 10^{-2}-5.17 \times 10^{-3} \mathrm{X}+5.48 \times 10^{-4} \mathrm{X}^{2}$; (B) CT (ם), $\mathrm{y}=$ $5.67 \times 10^{-2}-8.46 \times 10^{-3} \mathrm{X}+8.18 \times 10^{-4} \mathrm{X}^{2} ;$ DT $(\searrow), \mathrm{y}=5.67 \times 10^{-2}-4.28 \times$ $10^{-3} \mathrm{X}+7.00 \times 10^{-4} \mathrm{X}^{2} ; \mathrm{ZT}(\boldsymbol{\Delta}), 5.67 \times 10^{-2}-7.20 \times 10^{-3} \mathrm{X}+7.19 \times 10^{-4} \mathrm{X}^{2}$; NT ( ),$y=5.67 \times 10^{-2}-7.68 \times 10^{-3} \mathrm{X}+6.62 \times 10^{-4} \mathrm{X}^{2}$. 

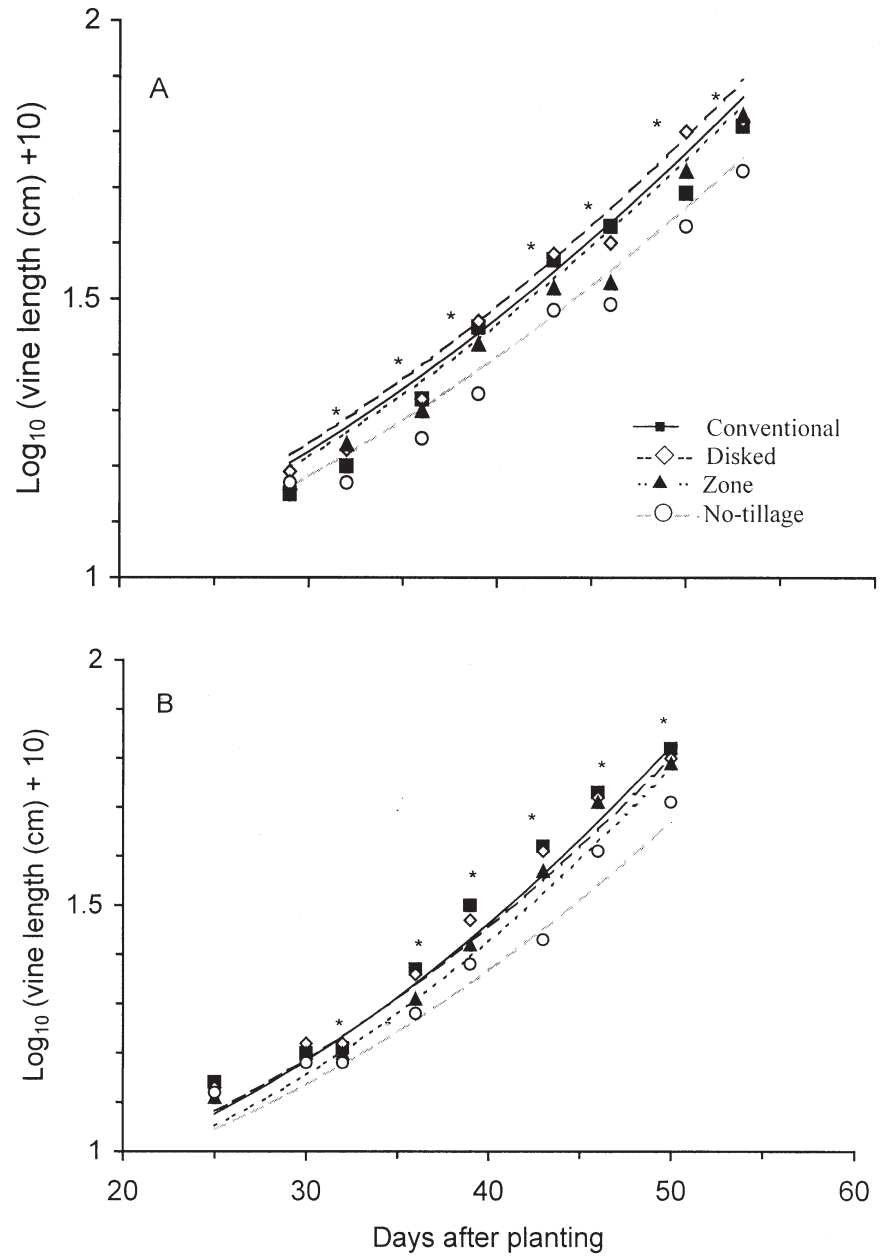

Fig. 4. Primary vine length per plant as influenced by tillage (conventional (CT), disked (DT), zone tillage (ZT) and no tillage (NT)) in (A) 2000 and (B) 2001. The asterisks indicate significance differences among treatment means within days, by pairwise $t$ test, $P \leq 0.05$. The regression equations were (A) CT (ם), $\mathrm{y}=8.56 \times 10^{-1}+3.75 \times 10^{-3} \mathrm{X}+2.88 \times 10^{-4} \mathrm{X}^{2} ; \mathrm{DT}(\diamond), \mathrm{y}=8.56 \times 10^{-1}$ $+4.10 \times 10^{-3} \mathrm{X}+2.92 \times 10^{-4} \mathrm{X}^{2} ; \mathrm{ZT}(\mathbf{\Delta}), 8.56 \times 10^{-1}+3.38 \times 10^{-3} \mathrm{X}+2.89$ $\times 10^{-4} \mathrm{X}^{2}$; NT ( ) $\mathrm{y}=8.56 \times 10^{-1}+2.96 \times 10^{-3} \mathrm{X}+2.64 \times 10^{-4} \mathrm{X}^{2}$; (B) CT (ם), $\mathrm{y}=8.56 \times 10^{-1}-1.71 \times 10^{-3} \mathrm{X}+4.22 \times 10^{-4} \mathrm{X}^{2} ; \mathrm{DT}(\searrow), \mathrm{y}=8.56 \times 10^{-1}$ $-8.25 \times 10^{-4} \mathrm{X}+3.95 \times 10^{-4} \mathrm{X}^{2} ; \mathrm{ZT}(\boldsymbol{\Delta}), 8.56 \times 10^{-1}-2.80 \times 10^{-3} \mathrm{X}+4.26 \times$ $10^{-4} \mathrm{X}^{2} ; \mathrm{NT}(\mathrm{)}) \mathrm{y}=8.56 \times 10^{-1}-1.11 \times 10^{-3} \mathrm{X}+3.48 \times 10^{-4} \mathrm{X}^{2}$.

Disked tillage had the greatest accumulation and no tillage the least. No differences were detected between conventional and zone tillage. These findings were in agreement with NeSmith et al. (1994), who found a decrease in total dry matter accumulation for summer squash between conventional tillage and no-

tillage treatments in the first 3 to 4 weeks of growth. Bottenberg et al. (1999) also found snapbean shoot dry weight to be the highest in conventional tillage compared to no-tillage rye mulch. Tillage, therefore, affects growth, which further influences cucumber development.

Time required for $50 \%$ of plants to produce

Table 4. Mean total aboveground dry matter, yield, and value of cucumbers, as influenced by tillage at Simcoe, Ont., in 2000 and $2001{ }^{\mathrm{z}}$ Dry matter values are back transformed means of $\log _{10}(\mathrm{x})$ transformed values.

\begin{tabular}{lccc}
\hline Treatment & $\begin{array}{c}\text { Aboveground dry matter } \\
\left(\mathrm{g} \cdot \mathrm{m}^{-2}\right)\end{array}$ & $\begin{array}{c}\text { Yield } \\
\left(\mathrm{t} \cdot \mathrm{ha}^{-1}\right)\end{array}$ & $\begin{array}{c}\text { Value } \\
(\$ / \mathrm{ha})\end{array}$ \\
\hline Conventional & $47 \mathrm{~b}^{\mathrm{y}}$ & $19.3 \mathrm{a}$ & $3712 \mathrm{a}$ \\
Disked & $50 \mathrm{a}$ & $23.4 \mathrm{a}$ & $4197 \mathrm{a}$ \\
$\quad$ Zone tillage & $42 \mathrm{~b}$ & $19.8 \mathrm{a}$ & $3614 \mathrm{a}$ \\
$\quad$ No tillage & $34 \mathrm{c}$ & $16.7 \mathrm{a}$ & $3138 \mathrm{a}$ \\
Standard error & $0.04^{\mathrm{x}}$ & 1.83 & 351.2 \\
$P$ value & $0.0001^{\mathrm{w}}$ & 0.1209 & 0.2410 \\
\hline
\end{tabular}

${ }^{2}$ Data was pooled across years (2000 and 2001).

${ }^{y}$ Mean separation within column, by pairwise $t$ test, $P \leq 0.05$. Values followed by a common letter, are not statistically different.

${ }^{\mathrm{x}}$ Standard error of mean is for means on the transformed scale.

wProbability value based on transformed analysis of variance. at least one open flower per plant differed between tillage systems. No-tillage cucumber plants required one additional day to develop to $50 \%$ flower compared to all other treatments, which required $42 \mathrm{~d}$ [SE $=0.4 ; P=0.0298$ (data not shown)]. NeSmith et al. (1994) found that squash maturity was delayed and fruit set lower in no tillage compared to conventional tillage. The growth data observed from this cucumber research follows the same general trends of other vine crop studies.

Yield. After analyses, all tillage treatments within the first harvest date were determined to be at the optimal stage of harvest for maximum yield for both 2000 and 2001 (O'Sullivan and Colwell, 1980). Only yield data from the first harvest date of each year are presented. Despite differences in growth and development, no differences were observed in yield $(P \leq 0.05)$ with tillage or year (Table 4$)$. Yield differences were only significant at values of $P=0.12\left(\mathrm{t} \cdot \mathrm{ha}^{-1}\right)$ and $P=0.24(\$ / \mathrm{ha})$. Disked tillage had the highest yield at $23.4 \mathrm{t} \cdot \mathrm{ha}^{-1}$ and the greatest returns of $\$ 4200 / \mathrm{ha}$, while no tillage had the lowest yield at $16.7 \mathrm{t} \cdot \mathrm{ha}^{-1}$ and returns of $\$ 3140 / \mathrm{ha}$. The additional cost of land preparation for conventional, disked, and zone tillage were $\$ 120, \$ 26$, and $\$ 36$ per hectare, respectively, compared to no tillage (Lonsbary, 2002). The lack of yield difference, despite the differences observed in growth, may be due to the physiological relationship between vegetative growth and final fruit set. Marcelis (1991) investigated the effects of fruit load on photosynthesis in greenhouse cucumbers. He found a positive correlation between fruit load and photosynthesis. As fruit number increased, more vegetation was required to support photosynthesis requirements. In contrast to greenhouse cucumbers, which produce additional fruit continuously, machine-harvested cucumbers produce only one to three fruit per plant, depending on variety and plant population (Staub et al., 1992). As a result, there is less photosynthetic demand on the plant. Once these fruit have reached their potential growth rate, the addition of new leaves will not change the final yield obtained. No yield differences were observed between no tillage compared to conventional tillage in a cucumber study by Knavel and Morrison (1977), nor in a squash study by NeSmith et al. (1994). The yield data reported in this study are, therefore, comparable with previous vine crop research.

In summary, cucumber seedling emergence was unaffected by a reduction in tillage, while cucumber plant growth and development differed between tillage treatments. The reduction in vegetative growth between reduced tillage treatments may actually prove to be a benefit for the mechanical harvest of the crop. Even though there were differences observed in cucumber plant growth and development, there were no yield differences observed between reduced tillage and conventional tillage treatments. Therefore, reduced tillage practices, such as disked or zone tillage, are viable alternative tillage practices for cucumber production. These alternative tillage practices will increase production efficiency, provide growers flexibil- 
ity with land preparation, reduce potential for soil erosion, and potentially increase economic return. However, to build a complete integrated crop management system for reduced tillage cucumbers, cultural practices such as plant spacing, fertilizer placement and weed control need to be investigated further.

\section{Literature Cited}

Beste, C.E. 1973. Evaluation of herbicides in no-till planted cucumbers, tomatoes and lima beans. Proc. N.E. Weed Sci. Soc. 27:232-239.

Bottenberg, H., J. Massiunas, and C. Eastman. 1999. Strip tillage reduces yield loss of snapbean planted in rye mulch. HortTechnology 9:235-240.

Bowley, S.R. 1999. A hitchhikers guide to statistics in plant biology. Plants et al., Guelph, Ont., Canada.

Button, T. 1999. Treatments too new for Publ. 75. Farm and Country, Spec. Rpt. 5 Apr. 1999. (http:// www.agpub.on.ca/iss/99/apr/sup1.htm).

Gallaher, R.N. 1977. Soil moisture conservation and yield of crops no-till planted in rye. Soil Sci. Soc. Amer. J. 41:145-147.

Galloway, B.A. and L.A. Weston. 1996. Influence of cover crop and herbicide treatment on weed control and yield in no-till sweet corn (Zea mays L.) and pumpkin (Cucurbita maxima Duch.). Weed Technol. 10:341-346.

Griffith, D.R., J.V. Mannering, and J.E. Box. 1986. Soil and moisture management with reduced tillage, p. 19-57. In: M.A. Sprague and G.B. Triplett (eds.). No-tillage and surface-tillage agriculture-The tillage revolution. Wiley,
New York.

Hooker, D.C., T.J. Vyn, and C.J. Swanton. 1998. Alternative weed management strategies in conservation tillage systems for white beans (Phaseolus vulgaris L.) Can. J. Plant Sci. 78:363-370.

Janovicek, K.J. and T.J. Vyn. 1992. Capacity of conservation tillage systems to reduce the potential for soil erosion. Information for industry personnel. OMAFRA and Univ. of Guelph. AGDEX No. 573.

Jones, J.N., Jr., J.E. Moody, and J.H. Lillard. 1969. Effect of tillage, no tillage, and mulch on soil water and plant growth. Agron. J. 61:719-721.

Knavel, D.E. and J. Morrison. 1977. The effect of tillage systems on the performance and elemental absorption by selected vegetable crops. J. Amer. Hort. Sci. 102:323-327.

Lonsbary, S.K. 2002. Crop management alternatives for machine harvested cucumbers (Cucumis sativus). MSc, Univ. of Guelph, Guelph, Ont., Canada.

Marcelis, L.F.M. 1991. Effects of sink demand on photosynthesis in cucumber. J. Expt. Bot. 42:1387-1392.

Morse, R.D. 1993. Components of sustainable production systems for vegetables-conserving soil moisture. HortTechnology 3:211-214.

Morse, R.D., C.M. Tessore, W.E. Chappell, and C.R. O'Dell. 1982. Use of no tillage for summer vegetable production. Veg. Growers News 37(1).

NeSmith, D.S., G. Hoogenboom, and D.V. McCraken. 1994. Summer squash production using conservation tillage. HortScience 29:28-30.

Ontario Ministry of Agriculture, Food, and Rural Affairs (OMAFRA). 2000. Vegetable production recommendations 2000-2001. Ont. Ministry
Agr. Food Rural Affairs, Toronto. Publ. 363, p. 74-79.

OMAFRA. 2001. OMAFRA web site. (http://www. on.ca/OMAFRA/english/stats/hort/index.html).

Ontario Processing Vegetable Growers. 2001a. Statistics-Cucumbers. Ont. Processing Veg. Growers 57th Annu. Rpt. p. 7.

Ontario Processing Vegetable Growers. 2001b. Ontario Processing Vegetable Growers 2000 information handbook. p. 36.

Ontario Processing Vegetable Growers. 2001c. Ontario Processing Vegetable Growers Nwsl. No.2.

O'Sullivan, J. and H.T.M. Colwell. 1980. Effect of harvest date on yield and grade distribution relationships for pickling cucumbers harvested onceover. J. Amer. Soc. Hort. Sci. 105:408-412.

Raghavan, G.S., V.E. McKeys, R. Baxter, and G. Gendron. 1979. Traffic-soil-plant (maize) relationships. J. Terramechanics 16:181-189.

Singh, B.P. and U.M. Sainju. 1998. Soil physical and morphological properties and root growth. HortScience 33:966-971.

Staub, J.E., L.D. Knerr, and H.J. Hopen. 1992. Plant density and herbicides affect cucumber productivity. J. Amer. Soc. Hort. Sci. 117:48-53.

Thomas, R.J., J. O'Sullivan, A. Hamill, and C.J. Swanton. 2001. Conservation tillage systems for processing tomato production. HortScience 36:1264-1268.

U.S. Dept. of Agriculture (USDA). 2001a. USDA web site. (http://usda.mannlib.cornell.edu/reports/nassr/fruit/pvg-bban/vgan0101.txt).

USDA. 2001b. USDA web site. (http://usda. mannlib.cornell.edu/reports/nassr/fruit/pvgbban/vgan0197.txt). 